\title{
Franz Josef Beranek a jeho výskum nemecky hovoriacich drevorubačov - Huncokárov
}

\author{
PAVOL KRAJČOVIČ
}

\author{
Filozofická fakulta Univerzity sv. Cyrila a Metoda v Trnave
}

\begin{abstract}
Franz Josef Beranek and his research of german speaking woodsmen Huncokars
\end{abstract}

\begin{abstract}
This paper deals with the person of sudetengerman ethnographic researcher Franz Josef Beranek and his research about the community of german speaking woodsmen - Huncokars. The first part is focused on the historico-geographical characteristics of huncokar settlements. The second part deals with the person of Beranek and his career. The third part deals with the Beranek's research of huncokar comunnity. Main goal of my study is analysis of scientific literature, articles or monographies written by Beranek, which deals with the Huncokars primarily or secondarily.
\end{abstract}

Keywords: Franz Josef Beranek, Huncokars, Ethnographic research, Little Carpathians, Western Slovakia, Nazi Germany.

DOI: https://doi.org/10.24040/ahn.2021.24.01.114-135

\section{Úvod ${ }^{1}$}

Po vzniku samostatnej Československej republiky v roku 1918 bol počet nemeckého obyvatel'stva tohto štátu zhruba tri milióny. Z majoritného národa $\mathrm{v}$ podunajskej monarchii sa zo dňa na deň stala menšina, ktorá z vel'kej časti nechcela byt' súčast'ou tohto štátu. A to aj napriek tomu, že prezident Tomáš Garrigue Masaryk (1850 - 1937) považoval nemeckú menšinu za neobyčajne dôležitú a jej uspokojenie pre nový štát za klúčové, jej zástupcovia de facto vznik republiky ani neuznali. To určilo smer ich politiky v najbližších rokoch, kedy prevládli negativistické tendencie, a to nielen na strane nemeckej, ale aj československej, ktorá cítila, že Nemcom nie je možné dôverovat' a bola ostražitá voči ich d'alšiemu postupu. ${ }^{2}$

V znamení boja za národné práva začala sudetonemecká ${ }^{3}$ menšina využívat' etnografický výskum, ktorý slúžil konkrétnym národnopolitickým

\footnotetext{
${ }^{1}$ Príspevok vznikol v rámci riešenia vedeckého projektu VEGA č. 1/0383/18 Dynamika a revitalizácia kultúrneho dedičstva v kontexte transformácie kolektívnej identity.

2 KURAL, Václav et al.: „Sudety“ pod hákovým křižem. Ústí nad Labem : Albis international, 2002, s. 20-23.

${ }^{3}$ Po roku 1918 sa začínalo presadzovat’ pre Nemcov žijúcich na území Čiech, Moravy a Sliezska všeobecné označenie „sudetskí Nemci“. Toto označenie vzniklo od pomenovania jednej 114
} 
Franz Josef Beranek a jeho výskum nemecky hovoriacich drevorubačov ...

ciel'om. Ciele a úlohy tohto výskumu načrtol sudetonemecký etnograf Gustav Jungbauer v roku 1928 nasledovne: „Tak ako všade, aj v prípade sudetonemeckých reálií má etnografický výskum tri stránky, a to zber materiálu, jeho vedecká analýza a uplatnenie získaných poznatkov v praxi, pri vzdelávaní l'udu. "4 Postupne od dvadsiatych rokov 20. storočia začali zástupcovia sudetonemeckých národno-vzdelávacích inštitúcií prichádzat' aj na Slovensko. ${ }^{5}$ Ich prínosom bola prednášková činnost’ týkajúca sa histórie nemeckého národa, d’alej zvykoslovia a folklórnych tradícií. V trid-

z tých provincií, ktoré sa chceli pripojit’ k Nemeckému Rakúsku, Sudetenland. Postupne sa začalo uplatňovat' ako označenie pre všetkých Nemcov žijúcich na území českých krajín. Pozri: GEBEL, Ralf: „Domů do říše “ Konrád Henlein a říšská župa Sudety (1938 - 1945). Praha : Argo, 2018, s. 43. Vo vzt’ahu k nemeckej menšine žijúcej na Slovensku sa používalo približne od prvej polovice 20. storočia označenie „karpatskí Nemci“ ( „Karpatendeutsche“), ktorého autorom bol rakúsky historik a etnológ Raimund Friedrich Kaindl. Pozri: HORVÁTHOVÁ, Margaréta: Nemci na Slovensku: etnokultúrne tradície z aspektu osídlenia, remesiel a odievania. Komárno : Fórum inštitút pre výskum menšín, 2002, s. 8. V dvadsiatych rokoch 20. storočia sa znížil význam pomenovania „karpatskí Nemci“ pre Nemcov žijúcich na Slovensku. V nadväznosti na to nazval sudetonemecký historik Hans Kaser v roku 1934 Nemcov žijúcich na Slovensku termínom „slovenskí Nemci“ (Slowakeideutsche). Bol zároveň prvým, kto tento termín oficiálne v odbornej literatúre použil. Pozri: KASER, Hans: Der Volks- und Kulturboden des Slowakeideutschtums. Breslau : Oesteuropa-Institut in Breslau, 1934, 196 s. Pre viac informácií k tejto téme Pozri: EGBERT, Jahn: Die Deutschen in der Slowakei in den Jahren 1918 - 1929. Ein Bitrag zur Nationalitätenproblematik. München - Wien : Oldenbourg Verlag, 1971, s. 14-15.

4 ZÜCKERT, Martin: Veda a „riadenie identity „, „Sudetonemeckí etnografi a ich vzt'ah k Slovensku na príklade časopisu „Karpathenland“ (1928-1938). In: Historický časopis, tom. 56, vol. 1, 2008, s. 147-160. Jungbauer na začiatku 30. rokov 20. storočia zastával názor, podl'a ktorého rozvoj sudetonemeckej etnografie slúžil predovšetkým na získanie teritória pre „„nemecký l'ud", bez priestoru (Volk ohne Raum). Pozri: KURLANDER, Eric: Hitler's Monsters: A Supernatural History of the Third Reich. New Haven, Connecticut : Yale University Press, 2017, s. 204. ${ }^{5}$ Boli to predovšetkým skupiny študentov nemeckých vysokých škôl z Prahy a Brna, ktorí pôsobili v mládežníckom hnutí tzv. "St'ahujúcich vtákov“ (Wandervogel). V spolupráci s miestnymi spolkami nemeckých kultúrnych zväzov (Deutscher Kulturverband) boli títo študenti pridelení do nemeckých miest a dedín $\mathrm{v}$ časoch žatevných prác. Ich prínosom bola prednášková činnost' týkajúca sa histórie nemeckého národa, zvykoslovia a folklórnych tradícií. Nemecký vybor národného vzdelávania v Litoměřiciach vyslal v lete v roku 1920 na Slovensko 16 dvoj až trojčlenných skupín študentov. Pozri: HORVÁTHOVÁ, M.: Nemci na Slovensku, s. 109. Zámery skupín sudetonemeckých „Wandervogel" sa v niektorých bodoch výrazne líšili od mládežníckeho hnutia v Nemeckej ríši. Kým mládežnícke organizácie v Nemecku pôsobili prevažne mimo etablovaných spoločenských štruktúr, záujmy sudetonemeckých „Wandervogel" sa zhodovali so záujmami mnohých etablovaných skupín Nemcov žijúcich v českých krajinách. Pozri: ZÜCKERT, M.: Veda a „riadenie identity“, s. 147-160. Medzi nemeckým obyvatel'stvom v Čechách a na Slovensku však v období prvej československej republiky existoval jeden podstatný rozdiel, ktorý sudetonemeckí bádatelia museli vo svojom výskume brat' do úvahy. Nemecké obyvatel'stvo na Slovensku, na rozdiel od sudetských Nemcov v Čechách, neobývalo nikdy súvislé územie. Bolo to spôsobené predovšetkým časovou disparitou príchodu jednotlivých skupín nemeckého obyvatel'stva. Dôsledkom toho bola geografická heterogenita ich osídlenia. Oblasti osídlenia možno geograficky rozdelit’ do troch väčších regiónov: 1. región juhozápadného Slovenska; 2. región stredného Slovenska; 3. spišský región. Pozri: GABZDILOVÁ-OLEJNÍKOVÁ, Soňa et al.: Karpatskí Nemci na Slovensku od druhej svetovej vojny 
siatych a štyridsiatych rokoch 20. storočia už bola vedecko-výskumná činnost' a z nej vychádzajúce publikácie ovplyvnené národnosocialistickou ideológiou prenikajúcou z vtedajšej Tretej ríše. ${ }^{6}$

V tomto období sa po prvý raz začali v odborných štúdiách, predovšetkým vlastived ného zamerania, spomínat' aj nemecky hovoriaci drevorubači - Huncokári žijúci predovšetkým na území pohoria Malých Karpát. Ich najrozsiahlejší výskum je spojený s nemeckým jazykovedcom, historikom osídlenia, etnografom a pedagógom Franzom Josefom Beranekom $(1902-1967) .^{7}$

V rámci môjho príspevku sa zaoberám osobou Beraneka a zároveň jeho výskumom Huncokárov. Obdobie jeho výskumu som v rámci príspevku rozdelil na dve časové etapy. Do prvej som zaradil obdobie rokov 1928 až 1930, počas ktorého pôsobil predovšetkým v Čechách a na Morave. Do druhej etapy obdobie rokov 1941 - 1943, kedy striedavo žil a pracoval na Slovensku. Ciel’om príspevku je analýza odborných prác, článkov či monografií Beraneka, ktoré sa Huncokármi zaoberajú primárne alebo sekundárne. Väčšina autorov sa doteraz zaoberala bud' Beranekovými aktivitami na Slovensku vo všeobecnosti ${ }^{8}$, alebo jeho spojitost'ou s nacistickým režimom Tretej ríše. ${ }^{9}$ Metodický postup s ciel’om analyzovat' Beranekov výskum Huncokárov tvoria predovšetkým:

do roku 1953. Bratislava : Spoločenskovedný ústav SAV - Slovenské národné múzeum-Múzeum kultúry karpatských Nemcov, 2004, s. 9.

${ }^{6}$ Napriek tomu, že sa záujem o „zahraničné nemectvo“ (Auslanddeutschtum) od počiatku dvadsiatych rokov 20. storočia vo zvýšenej miere prejavoval v samotnom Nemecku, zostáva faktom, že politická relevantnost' etnografického výskumu viedla pri tomto bádatel'skom záujme k nadproporčnému zastúpeniu etnografov pochádzajúcich z oblastí tzv. „zahraničného nemectva“. Práve v týchto regiónoch (predovšetkým stredovýchodnej Európy) bola najvýraznejšie pocit’ovaná potreba formulovat' novú ideológiu, ktorá by reagovala na územno-politické zmeny z rokov 1918 - 1920. Preto nie je náhoda, že medzi významnými bádatel'mi na tomto poli figuroval celý rad nemeckých národopiscov z Čiech, Moravy aj Sliezska. Medzi troma najvýznamnejšími predstavitel'mi akademického národopisu na pražskej Nemeckej Karlovej univerzite (Adolf Hauffen, Gustav Jungbauer, Josef Hanika) dokonca prevládal názor, že práve štúdium periférnych oblastí, teda nemeckého pohraničia prvej československej republiky a národnostných enkláv v nenemeckom prostredí, prináleží k hlavným špecifikám nemeckého národopisu v Čechách a na Slovensku. Pozri: LOZOVIUK, Petr et al.: Etnicita a nacionalismus v diskurzu 20. století: př́spěvek intelektuálů z českých zemí ke studiu kolektivních identit. Brno : Centrum pro studium demokracie a kultury, 2012, s. 18.

${ }^{7}$ KANTEK, Karol: Život spätý s lesom: Osudy zabudnutej nemeckej komunity v Malých Karpatoch. In: História, tom. 8, vol. 6, 2008, s. 33-35.

${ }^{8}$ KUBISA, Tomáš: Franz Beranek and his activities in Slovakia. In: Muzeológia a kultúrne dedičstvo. tom. 8, vol. 2, 2020, s. 76-89; PANCZOVÁ, Zuzana: Pôsobenie Franza J. Beranka na Slovensku v 30. a 40. rokoch 20. storočia: výskum „Huncokárov“ a Institut für Heimatforschung. In: Ethnologia Europae Centralis : Journal of Central European Ethnology. tom. 14, vol. 1, 2017, s. 23-39.

9 FAHLBUSCH, Michael et al.: Handbuch der völkischen Wissenschaften: Akteure, Netzwerke, Forschungsprogramme. Berlin : Walter de Gruyter, 2017, s. 1421-1427; HÖHNE, Stephen et al.: 
Franz Josef Beranek a jeho výskum nemecky hovoriacich drevorubačov ...

a) Heuristika ako metóda získavania a triedenia historických prameňov a informácií.

b) Kritická analýza prameňa a jeho následná interpretácia - zhromaždené pramene získané heuristikou je nevyhnutné zhodnotit' z hl'adiska ich historickej hodnoty, pravosti, vierohodnosti a vyt'ažit' z nich maximum, pre poznanie historickej skutočnosti. Z hl'adiska môjho výskumu je kritická analýza dôležitým prvkom na skúmanie objektívnej historickej reality. Výskumy a z nich vychádzajúce práce sudetonemeckých autorov totiž boli od tridsiatych rokov 20. storočia poznačené národnosocialistickou (nacistickou) ideológiou.

c) Biografická metóda - v práci som sa snažil využit' aj biografickú metódu. Jej ciel'om bolo vypracovat' individuálnu biografiu, ktorá by ukázala život Franza Josefa Beraneka v širších súvislostiach doby a prostredia. Postupoval som pri tom chronologicky od jeho narodenia až po jeho smrt', čo považujem v tomto prípade za najvhodnejšie. Ústredným obdobím Beranekovho života, na ktoré sa v práci zameriavam je však obdobie konca dvadsiatych rokov 20. storočia až po pät'desiate roky 20. storočia. $\mathrm{V}$ tomto časovom horizonte sa viac či menej venoval výskumu nemecky hovoriacich drevorubačov - Huncokárov. Beranekov život je zaujímavé sledovat' ako život typického predstavitel'a sudetonemeckej inteligencie narodeného po roku 1900. Patril k mladšej, radikálnejšej generácii. Študoval germanistiku a slavistiku. Neskôr nastúpil k útočným oddielom SA a stal sa členom NSDAP. ${ }^{10} \mathrm{~V}$ pomerne mladom veku bol zasiahnutý nacistickou ideológiou a tej neskôr podriadil svoj výskum. Aj preto sa zdá príhodné sledovat’ životné osudy a postupný myšlienkový vývoj človeka, ktorý svojimi výskumami ovplyvnil mladšie generácie a z ktorého výsledkami práce sa stretávajú dodnes odborníci z radov jazykovedcov, etnológov, historikov či dokonca judaistiky.

d) Vyššie uvedené metodické postupy mi umožnili syntetizovat’ a zároveň koncipovat' výsledky môjho výskumu.

Deutsche - Tschechen - Böhmen. Kulturelle Integration und Desintegration im 20. Jahrhundert. Köln - Wien - Weimar : Böhlau Verlag, 2010, s. 252-253; HUTTON, Christopher: Linguistics and the Third Reich: Mother-tongue fascism, race and the science of language. London - New York : Routledge, 1999, s. 212-220; MORRISEY, Christof: Ethnic Politics and Scholarly Legitimation: The German Institut für Heimatforschung in Slovakia, 1941 - 1944. In: German Scholars and Ethnic Cleansing, 1919 - 1945. Eds. I. Haar - M. Fahlbusch. New York - Oxford : Berghahn Books, 2005, s. 100-109; STEINWEIS, Alan: Studying the Jew. Scholarly Antisemitism in Nazy Germany. Cambridge, Massachussets : Harvard University Press, 2006, s. 152-156; VESELSKÁ, Magda: Jüdische Volkskunde in der Tschechoslowakei vor 1939? Eine Bestandsaufnahme. In: Österreichische Zeitschrift für Volkskunde. tom. 64/13, vol. 3, 2010, s. 457-473; WEISER, Kalman: "One of Hitler's Professors": Max Weinreich and Solomon Birnbaum confront Franz Beranek. In: The Jewish Quarterly Review . tom. 108, vol. 1, 2018, s. 106-124.

${ }^{10}$ KANTEK, K.: Život spätý s lesom, s. 33-35; PANCZOVÁ, Z.: Pôsobenie Franza J. Beranka na Slovensku, s. 23-39. 


\section{Historické a geografické charakteristiky huncokárskeho osídlenia}

Z dejinného hl'adiska zatial' nemáme podrobnejšie správy ani dostatočné archívne materiály dokladajúce jednoznačné okolnosti, príčiny a spôsob príchodu nemecky hovoriacich drevorubačov - Huncokárov ${ }^{11}$ na územie Slovenska. V odbornej literatúre zaoberajúcej sa príchodom nemeckých drevorubačov sa ich príchod dáva do súvislosti s privátnou kolonizáciou šl'achtickej rodiny Pálfiovcov. ${ }^{12}$ Tí boli v 18. storočí najväčšími pozemkovými vlastníkmi v rámci vtedajšej Bratislavskej stolice. Zároveň príchod drevorubačov mohol do vel'kej miery súvisiet' aj s merkantilistickou politikou habsburského panovníckeho dvora, ktorý sa usiloval hospodársky využit' dovtedy značne nevyužívané lesné priestory. ${ }^{13}$

Pôvod Huncokárov je nejednoznačný. Prichádzali predovšetkým z alpských oblastí nemeckých a rakúskych krajín. Najčastejšie sa medzi týmito krajinami uvádza Bavorsko, Horné Rakúsko, Dolné Rakúsko či Štajersko. ${ }^{14}$ Istá čast' kolonistov však pochádzala aj z územia Moravy a Sliezska. ${ }^{15} \mathrm{Na}$ územie juhozápadného Slovenska prichádzali vo viacerých kolonizačných etapách v priebehu celého 18. až začiatku 19. storočia. ${ }^{16}$ Jazyk, ktorým sa

${ }^{11}$ Pomenovanie Huncokár vzniklo z nemeckého pomenovania ich profesie Holzhacker či Holzfäller. Nazývalo ich tak majoritné, prevažne slovenské obyvatel'stvo okolitých malokarpatských obcí. Nemecky hovoriaci drevorubači vnímali toto pomenovanie (Huncokár) ako hanlivé. Sami seba nazývali predovšetkým Horskými či Lesnými l'ud'mi (Bergleute, resp. Waldleute). V odbornej etnologickej a historickej spisbe je etnonymum Huncokár zaužívané. Pozri: BOTÍK, Ján: Etnická história Slovenska: K problematike etnicity, etnickej identity, multietnického Slovenska a zahraničných Slovákov. Bratislava : Lúč, 2007, s. 92; SLOBODOVÁ-NOVÁKOVÁ, Katarína: Partnerský a erotický život v špecificky izolovanom horskom prostredí. In: Erotika v lidové kultuře. Zost. P. Číhal, Uherské Hradiště : Slovácké muzeum v Uherském Hradišti, 2017, s. 67-80.

12 BERANEK, Franz Josef: Die deutsche Besiedlung des Pressburger Grossgaus. München : Max Schick Verlag, 1941, s. 87; HABÁŇOVÁ, Gabriela: K problému zamestnaneckých vzt’ahov etnokultúrnej skupiny tzv. Huncokárov v Malých Karpatoch. In: Stredoeurópske kontexty l'udovej kultúry na Slovensku. Zost. J. Michálek, Bratislava : Stimul, 1995, s. 144-154; SCHEWITZ, Ilona: Pressburg und Umgebung: Lage, Wirtschaft und Deutschtum. Tübingen : Günthers Buchdruckerei, 1932, s. 80.

13 MAREK, Miloš: Národnosti Uhorska. Vysokoškolský učebný text. Trnava : Filozofická fakulta v Trnave, 2011, s. 285-286.

${ }^{14}$ BERANEK, F. J.: Die deutsche Besiedlung, s. 69; HORVÁTHOVÁ, M.: Nemci na Slovensku, s. 29. 15 FOCHLER-HAUKE, Gustav: Deutscher Volksboden und Deutsches Volkstum in der Tschechoslowakei: Eine geographisch-geopolitisch Zusammenschau. Heidelberg : Kurt Vowinckel, 1937, s. 174.

16 SLOBODOVÁ-NOVÁKOVÁ, Katarína et al.: Rozšírenie kultu sv. Vincenta na Slovensku a v Rakúsku ako výsledok migrácií alpských drevorubačov v priebehu 18. storočia. In: Slovenský národopis. tom. 68, vol. 1, 2020, s. 7-28. Príchod Huncokárov na územie Slovenska považuje Péter Kárpáty z historického hl'adiska ako tretiu až štvrtú etapu osídlovania Slovenska nemeckým obyvatel'stvom. Pozri: KÁRPÁTY, Péter: Karpatskí Nemci a nemecká otázka na Slovensku. In: Folia geographica. tom. 38, vol. 6, 2002, s. 41-53. V matričných záznamoch 
Franz Josef Beranek a jeho výskum nemecky hovoriacich drevorubačov ...

títo nemecky hovoriaci drevorubači dorozumievali, je zásluhou nedávneho akademického výskumu prirad'ovaný k stredobavorskému nárečiu (mittelbairisch). ${ }^{17}$

Profesijne boli Huncokári zameraní predovšetkým na prácu v lese, čo je predpokladom toho, že si so sebou priniesli štýl života charakteristický pre spoločenstvá žijúce v lesnom prostredí. Popritom sa zaoberali vysádzaním nových stromov, rezbárskou, šindliarskou činnost’ou a inými prácami súvisiacimi s drevom. ${ }^{18}$ Čast' z nich taktiež vykonávala profesiu hájnikov, horárov a uhliarov.

Huncokári nebudovali žiadne osady. Po svojom príchode žili rozptýlene na usadlostiach nachádzajúcich sa priamo v horskom prostredí Malých a čiastočne Bielych Karpát. ${ }^{19}$ Panstvo pre nich vybudovalo domy v podobe drevených horární s dvoma až štyrmi bytmi, ktoré obsahovali izbu, pitvor, kuchyňu a komoru. Horáreň dostávali do bezplatného užívania v konkrétnej lokalite, na ktorú sa ich práca vzt'ahovala. ${ }^{20}$ Výnimku medzi huncokárskymi usadlost’ami tvorí azda najznámejšia lokalita Modra-Piesok. Je to spôsobené tým, že toto drevorubačské sídlo tvorilo niekol'ko obývaných domov, ku ktorým prislúchali záhrady. ${ }^{21}$

Na základe prvých údajov z konca 18. storočia žilo na Slovensku zhruba 500 Huncokárov. V prvej polovici 20. storočia sa ich počet zvýšil na takmer 800.22 Približne od roku 1850 sa čast’ Huncokárov žijúcich v

z druhej polovice 18. storočia sú Huncokári evidovaní ako príslušníci katolíckeho vierovyznania bez udania krajiny pôvodu či miesta narodenia. V záznamoch je uvádzané, že pochádzajú $z$ lesov (ex sylvis), či z hôr (ex montibus). Častokrát je zapísaná taktiež ich drevorubačská profesia (lignicida/lignisector) Pozri: HABÁŇOVÁ, G.: K problému zamestnaneckých vzt'ahov, s. 144-154.

17 FEDIČ, Dušan: Analysis of Huncokars' Dialect. In: Ethnologia Actualis. tom. 14, vol. 2, 2014, s. 109-119.

${ }^{18}$ BLAŽO, Jozef: Po stopách Huncokárov. In: Lesník. tom. 1, vol. 4, 2003, s. 11.

${ }^{19}$ HORVÁTHOVÁ, M.: Nemci na Slovensku, s. 29. Po prvý raz sa spomínajú usadlosti nemecky hovoriacich drevorubačov v Malých Karpatoch v Štatistickom výkaze Bratislavskej župy (Statistische Nachweisungen über das Pressburger Comitat) z roku 1866, ktorý vydala komora priemyslu a obchodu. Uvádza sa tu, že v Malých Karpatoch sa nachádzajú v jednotlivých horských údoliach osamotené drevorubačské usadlosti, ktoré sú obývané nemeckým obyvatel'stvom, ktoré sem prišlo v 18. storočí. Pozri: Statistische Nachweisungen über das Pressburger Comitat. Pressburg : Druck von Alois Schreiber, 1866, s. 176.

${ }^{20}$ SLOBODOVÁ-NOVÁKOVÁ, K.: Partnerský a erotický život, s. 67-80.

21 SCHEWITZ, I.: Pressburg und Umgebung, s. 80.

22 BERANEK, F. J.: Die deutsche Besiedlung, s. 87. Na základe súčasných výskumov sa predpokladá, že Huncokári žili rozptýlení vo viac než 49 sídlach prevažne charakteru samôt. Tento údaj sa však týka len geomorfologického podcelku pohoria Malých Karpát, a to Pezinských Karpát. K d'alším geomorfologickým podcelkom a taktiež k usadlostiam nachádzajúcim sa v pohorí Bielych Karpát v súčasnosti prebiehajú historicko-geografické výskumy. Pozri: KRAJČOVIČ, Pavol: Problematika huncokárskeho osídlenia v Malých Karpatoch na starých mapách. In: My a Oni - Domácí a cizí v lidové tradici. Zost. P. Číhal, Uherské Hradiště : Slovácké muzeum v Uherském Hradišti, 2019, s. 133-142. 
Malých a Bielych Karpatoch presunula na druhú stranu rieky Váh, kde postupne zakladali niekol'ko usadlostí na území pohoria Považského Inovca. Obývali tu zväčša kopanice v blízkosti tamojších obcí. ${ }^{23}$

Vobdobí existencie prvej Československej republiky dochádzalo k narušeniu tradičného spôsobu huncokárskeho života. Deti začali postupne dochádzat’ do škôl v spádových obciach, zväčša na obdobie jedného týždňa, a menit' sa začal aj celý systém lesných prác. ${ }^{24}$ Po skončení druhej svetovej vojny bola čast’ Huncokárov v dôsledku tzv. Benešových dekrétov násilne vysídlená do povojnového Nemecka a Rakúska. ${ }^{25}$ Tí, čo ostali žit' na Slovensku sa museli prispôsobit' novým celospoločenským podmienkam. Ich potomkovia sa v súčasnosti aktívne hlásia ku kultúrnemu dedičstvu svojich predkov, identifikujú sa s nimi a snažia sa o revitalizáciu. ${ }^{26}$

\section{Osoba Franza Josefa Beraneka a jeho kariéra}

Franz Josef Beranek sa narodil 8. augusta $1902 \mathrm{v}$ juhomoravskom meste Břeclav. ${ }^{27}$ Narodil sa do železničiarskej rodiny Bohumíra Beránka a jeho manželky Antónie, rodenej Ježkovej. Napriek tomu, že mal po oboch rodičoch český pôvod, hrdo sa v dospelosti hlásil k Nemcom. ${ }^{28}$ Po maturite na nemeckom štátnom gymnáziu $v$ Břeclavi začal študovat' germanistiku a slavistiku vo Viedni. Zaujímala ho predovšetkým náuka o dialektoch (Mundartkunde). Po dvoch rokoch začal študovat' na Nemeckej Karlovej univerzite v Prahe. ${ }^{29}$ Tu následne získal aj doktorát z filológie. ${ }^{30}$

\footnotetext{
${ }^{23}$ HORVÁTHOVÁ, M.: Nemci na Slovensku, s. 29; MAREK, M.: Národnosti Uhorska, s. 287. Populačné údaje o nemecky hovoriacich drevorubačoch žijúcich v oblasti Považského Inovca neboli predmetom širšieho vedeckého záujmu a z tohto dôvodu je v súčasnosti zložité určit' ich čo i len približný počet.

${ }^{24}$ HORVÁTHOVÁ, M.: Nemci na Slovensku, s. 30.

25 PANCZOVÁ, Z.: Pôsobenie Franza J. Beranka na Slovensku, s. 23-39. Ohl'adne perzekúcií Huncokárov po skončení druhej svetovej vojny. Pozri: PETRANSKÝ, Ivan Albert: Perzekúcie nemeckých drevorubačov v Modre v rokoch 1945 - 1950. In: Studia Historica Nitriensia. tom. 23, vol. 2, 2019, s. 488-507.

${ }^{26}$ LENOVSKÝ, Ladislav: The language, identity and culture of ethnic minorities in the Central European contexts. In: Xlinguae, European scientific language journal. tom. 11, vol. 4, 2018, s. $125-142$.

27 Vtedy malo mesto nemecký názov Lundenburg.

${ }^{28}$ NOVOTNÝ, René: Národnost, rasa a pospolitost. Německé obyvatelstvo v Protektorátu Čechy a Morava : Disertační práce. Pardubice : Univerzita Pardubice, 2019, s. 346.

${ }^{29}$ SCHWARZ, Ernst: Nachruf - Franz J. Beranek (8. 8. 1902 - 11. 8. 1967). In: Die Jahrbücher des Collegium Carolinum. Forschungsstelle für die böhmischen Länder. Band 9. hg. K. Bosl, München : Verlag Robert Lerche, 1968, s. 401-403.

$30 \mathrm{~V}$ tomto období už začal používat' nemeckú variantu svojho mena - Franz Josef Beranek. $\mathrm{V}$ tridsiatych rokoch 20 . storočia, ked' sa živil ako učitel' nemčiny na českých školách používal naopak český variant svojho mena dr. František Josef Beránek. Pozri: NOVOTNÝ, R.: Národnost, rasa a pospolitost, s. 346.
} 
Franz Josef Beranek a jeho výskum nemecky hovoriacich drevorubačov ...

Napriek tomu, že Beranek krátko po svojich štúdiách pracoval ako stredoškolský profesor, bol zapáleným vedcom. Na rodnej Morave začal vykonávat' terénny výskum formou návštevy rôznych usadlostí, na ktorých žilo prevažne obyvatel'stvo nemeckého pôvodu. Tamojších l'udí sa pýtal predovšetkým na ich nárečie. Poznatky a materiály z terénnych výskumov následne v roku 1936 spracoval v monografii s názvom Nárečie z južnej Moravy: Fonetika (Die Mundart von Südmähren: Lautlehre). ${ }^{31}$ $\mathrm{V}$ tom istom roku sa stal učitel'om nemčiny na obchodnej škole (neskoršia obchodná akadémia) v Pardubiciach. Príchodom do tohto mesta objavil novú výskumnú tému - zaniknuté nemecké osídlenie v Pardubickom kraji, ktorý považoval za jazykový či národnostný ostrov (Volksinsel). ${ }^{32}$ Zaujímavost'ou Beraneka je jeho vzt'ah k židovskému jazyku - jidiš. Po prvý raz sa s ním zoznámil v roku 1927 počas návštevy Podkarpatskej Rusi. Jidiš ho zaujal natol'ko, že po d'alších cestách po vtedajšom Pol'sku, Mad'arsku a baltských štátoch sa stal jedným z najuznávanejších odborníkov na tento jazyk v rámci celej strednej Európy. ${ }^{33}$

Svoj výskum v tomto období vykonával pod záštitou Sudetonemeckého vlastivedného výskumu (Anstalt für Sudetendeutsche Heimatforsch-

31 SCHWARZ, E.: Nachruf, s. 401-403. Ešte pred vydaním svojej knihy o juhomoravskom nárečí vystupoval Beranek s touto tematikou na niekol'kých konferenciách. Príkladom je prednáška v Mikulove (Nikolsburg), ktorú usporiadalo vedenie Zväzu Nemcov na južnej Morave (Bundes der Deutschen in Südmähren). Pozri: Veranstaltungen: Zweite südmährische heimatwoche. In: Tagesbote Jahrgang 78, vol. 592, 1928, s. 6. Zásady vedeckého skúmania juhomoravského nárečia publikoval v rovnomennom článku na stránkach periodika Neues Pressburger Tagblatt. Pozri: BERANEK, Franz Josef. Grundsätzliches zur südmährischen Mundartforschung. In: Neues Pressburger Tagblatt. tom. 2, vol. 101, 1931, s. 12.

${ }^{32}$ NOVOTNÝ, R.: Národnost, rasa a pospolitost, s. 347. Beranekove zistenia z pardubického jazykového ostrova sú z dnešného hl'adiska nedocenitel'né, pretože už nie je nik, kto by o etnografickej svojráznosti vtedajšieho nemeckého obyvatel'stva niečo konkrétne vedel. Pozri: NOVOTNÝ, René: Příspěvek k dějinám zaniklého německého osídlení na Pardubicku: předpoklady a východiska. In: Východočeský sborník historický. tom. 29, vol. 1, 2016, s. 79-141.

33 SCHWARZ, E.: Nachruf, s. 401-403. S Beranekom a jeho štúdiom jazyka jidiš sa spája aj značná kontroverzia. Krátko po vojne sa totiž snažil spolupracovat's viacerými odborníkmi na jidiš, ktorí mali židovský pôvod. Tí však s ním odmietli spolupracovat' vzhl'adom na jeho minulost'. Značnú pozornost' venoval Beranekovi predovšetkým jazykovedec židovského pôvodu a zároveň spoluzakladatel’ Židovského vedeckého inštitútu (YIVO) Max Weinreich. Ten v roku 1956 publikoval na stránkach newyorského židovského časopisu Forverts dva články, v ktorých ostro kritizoval Beranekovu kariéru. Nazval ho dokonca „jedným z Hitlerových profesorov". Beranek sa však bránil, že jeho pôsobenie v nacistických organizáciách bolo podmienené výlučne k prospechu vedy. Diametrálne odlišný vzt'ah mal Beranek so židovským lingvistom Solomonom Birnbaumom. Viedol s ním pravidelnú korešpondenciu a obaja sa vzájomne rešpektovali. Pozri: STEINWEIS, A.: Studying the Jew, s. 156; WEISER, K.: „One of Hitler's Professors“, s. 106-124. Beranek je považovaný za unikát spomedzi ostatných nacistických vedeckých pracovníkov. Jeho práce o jidiš sú aj v dnešnej dobe používané mnohými lingvistami zaoberajúcimi sa týmto židovským jazykom. Pozri: HUTTON, Ch.: Linguistics and the Third Reich, s. 219-220. 
ung $)^{34}$ a neskôr pracoval aj v Sudetonemeckom ústave pre výskum zeme a l'udu (Sudetendeutsche Anstalt für Landes- und Volksforschung). ${ }^{35}$

Beranekova kariéra však nie je spojená len s vedeckým výskumom. Napriek českému pôvodu sa cítil byt' sudetským Nemcom a prejavoval náklonnost' k rozmáhajúcej sa Sudetonemeckej strane (Sudetendeutsche Partei) pod vedením Konráda Henleina. So svojím učitel'ským kolegom Eduardom Kurzom opustil v roku 1938 pardubickú obchodnú akadémiu a pridal sa k sudetonemeckým bojovým skupinám pôsobiacim v pohraničí. Neskôr v tom istom roku sa stal členom NSDAP a taktiež SA. ${ }^{36}$

Po vzniku Protektorátu Čechy a Morava sa Beranek vrátil k vedeckej práci. Okrem práce o jazykových ostrovoch v Čechách a na Morave začal pôsobit' na území vtedajšieho Slovenského štátu. ${ }^{37}$ Od roku 1942 sa spolu s manželkou Herthou Wolf-Beranek ${ }^{38}$ ujal vedúcej pozície na Inšti-

34 JOSEFOVIČOVÁ, Milena: Německé vědecké instituce v Liberci 1923 - 1945: od vlastivědy $k$ nacistickému „bádání o zemi a lidu“. Praha : Masarykův ústav a Archiv AV ČR, 2014, s. 37. Ústav fungoval v rokoch 1924 až 1939. Oficiálne však bol založený v roku 1925. Práve od tohto dátumu organizoval ústav nasledujúcich pätnást' rokov celý rad projektov zameraných na sudetonemecký výskum v rozsahu od vlastivedy, histórie, kultúrnych dejín, národopisu až po archeológiu. Pozri: NĚMEC, Jiří: Eduard Winter 1896 - 1982. Zpráva o originalitě a přizpůsobení se sudetoněmeckého historika. Brno : Filozofická fakulta, Masarykova univerzita, 2017, s. 53.

35 JOSEFOVIČOVÁ, M.: Německé vědecké instituce v Liberci, s. 13. Ústav fungoval v rokoch 1938 až 1946. V časovom období $(1940$ - 1945) však bol transformovaný podla politických požiadaviek nacistického Nemecka. Do výskumu v rámci tohto ústavu bolo zapojených viac než 300 bádatel'ov predovšetkým sudetonemeckého pôvodu. Podl'a výskumnej správy z roku 1943 bolo do výskumnej práce zapojených celkovo 176 riadnych a 138 mimoriadnych členov ústavu, ktorí pôsobili v desiatich odborných komisiách. Beranek pôsobil v Odbornej komisii pre sídelný a jazykový výskum (Kommision für Siedlungs- und Sprachforschung). Pozri: JOSEFOVIČOVÁ, M.: Německé vědecké instituce v Liberci, s. 13-14.

${ }^{36}$ NOVOTNÝ, R.: Národnost, rasa a pospolitost, s. 352; V rámci SA, získal hodnost' velitela družstva (Scharführer) a zároveň tlačového dôstojníka (Presseoffizier), čo bol v tej dobe ekvivalent pre hovorcu miestnej organizácie SA. Pozri: HÖHNE, S.: Deutsche - Tschechen Böhmen, s. 253. Ešte počas študentského pobytu vo Viedni pôsobil Beranek v radikálnom nacionalistickom spolku (Germanistenverein). Pozri: PANCZOVÁ, Z.: Pôsobenie Franza J. Beranka na Slovensku, s. 23-39. Vzt'ah Beraneka k nacistickej ideológii je zložité určit'. Vo svojich textoch sa vyhýbal priamym prejavom sympatií k nacizmu. Na druhej strane sa aspoň čiastočne nechal inšpirovat' vtedajšími rasovými teóriami. Pozri: NOVOTNÝ, R.: Národnost, rasa a pospolitost, s. 352. Počas pôsobenia v Kežmarku lektoroval články svojich spolupracovníkov, ktorí mali k nacistickému Nemecku otvorene pozitívny vzt’ah. Príkladom toho je Johan Lang, ktorý dokonca z nárečia nemeckého obyvatel'stva z Mníška nad Hnilcom (Einsiedel an der Göllnitz) vytvoril oslavnú báseň na počest' Adolfa Hitlera. Pozri: LANG, Johann: Gedichte in der Mundart von Einsiedel. In: Deutsche Stimmen. tom. 10, vol. 6, 1943, s. 5.

37 Tematike Nemcov žijúcich na Slovensku sa venoval aj v období dvadsiatych a tridsiatych rokov 20. storočia. Tento výskum však nebol vedený v takej kvalitatívnej rovine ako počas jeho neskoršieho pôsobenia, v období rokov 1942 až 1943.

${ }^{38}$ Hertha Wolf-Beranek sa narodila 24. júla 1912 v Bohosudoch (Mariaschein), dnes čast' obce Krupka, ktorá sa nachádza v severných Čechách. Od roku 1931 študovala na pražskej Nemeckej Karlovej univerzite slavistiku, germanistiku a národopis. Od roku 1936 do roku 
Franz Josef Beranek a jeho výskum nemecky hovoriacich drevorubačov ...

túte pre výskum vlasti ${ }^{39}$ (Institut für Heimatforschung - IHF) v Kežmarku. ${ }^{40}$ Svojím výskumom na Spiši mali manželia Beranekovci podporit' snahy vtedajšieho predsedu Nemeckej strany na Slovensku Franza Karmasina. Ten od nich očakával, že svojím výskumom podporia národnobuditel'sko-emancipačné snahy a zároveň posunú počiatky nemeckej kolonizácie Spiša na skorší dátum než bol dovtedy uvádzaný v odbornej literatúre. Počas tohto obdobia sa Beranek koncepčne venoval nemeckému osídleniu na Slovensku. Lektoroval články ostatných kolegov z Inštitútu, zúčastňoval sa na vedeckých konferenciách a napísal viacero článkov či odborných štúdií. ${ }^{41}$ Ked'že sa vel'ká čast' z jeho materiálov stratila, ostávajú mnohé jeho štúdie roztrúsené po periodikách vtedajšej nemeckej menšiny na Slovensku. ${ }^{42}$ Okrem toho písal nad'alej aj o jazyku

1942 bola odbornou asistentkou profesora Gustava Jungbauera. Doktorát získala z odboru národopisu. V roku 1942 so svojím manželom Franzom Josefom Beranekom odišla pracovat' ako riaditel'ka do Inštitútu pre výskum vlasti v Kežmarku. Po odchode zo Slovenska sa vrátila do Prahy, kde pracovala až do mája 1945 ako odborná asistentka pri profesorovi slavistiky Edmundovi Schneeweisovi na národopisnom oddelení Inštitútu slavistiky na Nemeckej Karlovej Univerzite. Po skončení vojny bola s manželom vyst'ahovaná do Hesenska. Zomrela 2. júna 1977 v Giessene. Pozri: SCHWARZ, Ernst: Zum Tode von Dr. Hertha WolfBeranek (1912 - 1977). In: Bohemia: Zeitschrift für Geschichte und Kultur der böhmischen Länder. tom. 18, vol. 1, 1977, s. 407-408.

${ }^{39}$ Beranek nahradil na riaditel'skom poste Inštitútu dovtedajšieho riaditel’a Johana Liptáka. V kontraste voči Liptákovi reprezentovali Beranek a jeho manželka moderný akademický výskum v Tretej ríši. Manželia sa zároveň pýšili dobrými kontaktmi na vedúcu siet' vtedajších akademikov. Ríšske orgány ich považovali za politicky spol’ahlivejšie osoby než bol Lipták. Ten bol totiž ženatý so ženou, ktorá mala mad'arský pôvod a okrem toho bol členom slobodomurárskej lóže. Vzhl'adom na okolnosti strácal v očiach Nemeckej strany dôveru. Pozri: FAHLBUSCH, M.: Handbuch der völkischen Wissenschaften, s. 1421-1427. Pre viac informácií ohl'adne fungovania Vlastivedného inštitútu v Kežmarku pozri: FETKO, Filip: "Institut für Heimatforschung" in Käsmark - Wissenschaftliche Einrichtung und ihre politische Funktion. In: Pocta Ivanovi Chalupeckému. Zborník príspevkov k slovenským dejinám vydaný pri príležitosti osemdesiatin doc. PhDr. Ivana Chalupeckého. zost. F. Fetko, Levoča : Spišský dejepisný spolok, 2012, s. 226-235.

${ }^{40}$ Inštitút bol založený 9 . januára 1941 v Kežmarku s podporou Nemeckej strany na Slovensku (Deutsche Partei) a Strediska na podporu etnických Nemcov (Volksdeutsche Mittelstelle - VoMi). Koncipovaný bol predovšetkým ako inštrument kultúrnej a politickej „glajchšaltácie" slovenských Nemcov ako celku. Medzi hlavné úlohy Inštitútu malo pôvodne patrit' vybudovanie ústrednej knižnice národnostnej skupiny (Volksgruppe), vybudovanie rozsiahlej fotodokumentácie, podpora literárnej a vedeckej tvorby, výchova vedeckého dorastu a archívnictvo. Pozri: SCHVARC, Michal: „Kulturraub“ alebo záchrana kultúrneho dedičstva? Evakuácia archívov a kultúrnych pamiatok nemeckými orgánmi zo Slovenska koncom 2. svetovej vojny. In: Muzeológia a kultúrne dedičstvo. tom. 1, vol. 1, 2013, s. 75-82.

${ }^{41}$ KANTEK, K.: Život spätý s lesom, s. 33-35.

42 Vel'ká čast' článkov o nemeckom obyvatel'stve na Slovensku od Beraneka sa nachádza predovšetkým v týždenníku nemeckej komunity na Slovensku s názvom: Nemecké hlasy (Deutsche Stimmen). Toto periodikum bolo tlačovým orgánom Karpatonemeckej, neskôr Nemeckej strany. Vychádzal od novembra 1934, do marca roku 1945. Pozri: FEDOR, Michal 
jidiš. ${ }^{43}$ V roku 1943 sa habilitoval a o rok neskôr sa stal mimoriadnym profesorom etnológie (Volkskunde) pre kmeňové dejiny Moravy na $\mathrm{Ne}$ meckej Karlovej univerzite v Prahe. ${ }^{44}$ Nadviazal taktiež nepriamu spoluprácu s Nadáciou Reinharda Heydricha (Reinhard Heydrich-Stiftung), ${ }^{45}$ pre ktorú spracovával štúdiu na tému novovekého nemeckého osídlenia v Čechách. ${ }^{46}$ Svoje štúdie v tomto období publikoval predovšetkým v odborných časopisoch, akými boli napríklad Nemecký l'udový výskum v Čechách a na Morave (Deutsche Volksforschung in Böhmen und Mähren) ${ }^{47}$ a Karpatsko (Karpathenland). ${ }^{48}$

V decembri roku 1943 Beranek spolu s manželkou opustil Slovensko a odišiel do Prahy. Po skončení druhej svetovej vojny bol nútený opustit' územie Čiech a začal pôsobit' v Hesensku a od roku 1962 na univerzite v Giessene. ${ }^{49}$ Po vojne pokračoval nad'alej vo výskumnej činnosti a okrem iného pracoval na vydaní Atlasu sudetonemeckého hovorového jazyka (Atlas der Sudetendeutschen Umgangsprache). ${ }^{50}$ Prvý zväzok tohto dovedna

et al.: Súpis novín a časopisov na Slovensku za roky 1939 - 1944. Čast’ druhá. Martin : Matica slovenská, 1960, s. 123.

${ }^{43} \mathrm{~V}$ snahe o získanie lingvistických dát Beranek dokonca navštívil ortodoxného trnavského rabína Izidora Friedmana. Stretnutie prebehlo v čase, kedy boli židia na Slovensku prenasledovaní a deportovaní. Pozri: WEISER, K.: „One of Hitler's Professors”, s. 106-124.

${ }^{44}$ MORRISEY, Ch.: Ethnic Politics, s. 100-109. K tejto funkcii mu dopomohli aj styky s nacistickou organizáciou - Dedičstvo predkov (Ahnenerbe). Pozri: NOVOTNÝ, R.: Národnost, rasa a pospolitost, s. 79-141; PANCZOVÁ, Z.: Pôsobenie Franza J. Beranka na Slovensku, s. 2339. Organizácia Dedičstvo predkov (Ahnenerbe) zastávala významné miesto pri formovaní ideológie ochranných oddielov SS (Schutzstaffel) nacistického Nemecka. Založená bola 1. júla 1935 a za svoj ciel' si stanovila výskum dosahu ducha, činov a dedičstva indogermánskej nordickej rasy. Sekundárne sa snažila sprostredkovat' výsledky svojich výskumov čo najzaujímavejšou formou širokej verejnosti. Antropológovia a etnografovia spolupracujúci s Ahnenerbe sa podiel'ali na expedíciách do rôznych kútov sveta. Tieto výskumy mali za ciel' objavit' stopy tam existujúcej germánskej prakultúry, zdôvodnit' rasovú nadradenost' Germánov a predovšetkým zdôvodnit' ich odveké právo zohrávat' vedúcu úlohu v celosvetovom meradle. Pozri: GRÜNBERG, Karol: SS - Hitlerova černá garda. Praha : Nakladatelství Svoboda, 1981, s. 109-111.

45 Nadácia Reinharda Heydricha (Reinhard Heydrich Stiftung) sa v rokoch 1942/1943 až 1945 stala centrálnou vedeckou inštitúciou nacistického režimu v Protektoráte Čechy a Morava. Bola zriadená ríšskym protektorom s ciel’om prípravy účelových štúdií a odborných podkladov pre nacistických okupantov. Pozri: NĚMEC, Jiří: Pražská věda mezi Alfredem Rosenbergem a Reinhardem Heydrichem. K prehistorii Říšské nadace Reinharda Heydricha pro vědecká bádání v Praze. In: Studia Historica Brunensia. tom. 58, vol. 2, 2011, s. 85-105. ${ }^{46}$ NOVOTNÝ, R.: Národnost, rasa a pospolitost, s. 352-353.

47 Tento časopis bol založený v roku 1939 a vychádzal až do roku 1944. Bol zameraný predovšetkým na etnografické výskumy. Pozri: NOVOTNÝ, R.: Národnost, rasa a pospolitost, s. 188. 48 Časopis bol založený v roku 1928 v severočeskom Liberci. Mal slúžit' ako platforma na podporu vedeckého výskumu na Slovensku. Od roku 1941 sa nemecký názov pre Karpatsko Karpathenland - písal bez „h“. Pozri: ZÜCKERT, M.: Veda a „riadenie identity“, s. 147-160.

${ }^{49}$ NOVOTNÝ, R.: Národnost, rasa a pospolitost, s. 353; SCHWARZ, E.: Nachruf, s. 401-403.

${ }^{50}$ Prvotná myšlienka na spracovanie sudetonemeckých nárečí pochádza podl’a slov Herthy Wolf-Beranek z roku 1930. Vzišla od nemeckého jazykovedca Theodora Fringsa, ktorý bol 
Franz Josef Beranek a jeho výskum nemecky hovoriacich drevorubačov ...

trojzväzkového diela však vyšiel až tri roky po jeho smrti v roku 1970. Beranek zomrel v roku 1967 v Giessene. ${ }^{51}$

\section{Beranek a Huncokári}

Beranek sa podl'a svojich vlastných slov dozvedel o menšine nemecky hovoriacich drevorubačov - Huncokárov počas svojho pobytu v Bratislave v máji 1928.52 Osobou, ktorá mu o nich podala prvotné informácie bol jeho priatel' Samuel Sandtner. ${ }^{53} 0$ nutnosti skúmania ho definitívne presvedčila správa Viedenčana Wilhelma Biera. Ten v roku 1929 na stretnutí Nemeckého kultúrneho zväzu (Deutscher Kulturverband) referoval o svojej ceste po malokarpatských lesoch. Počas nej podl'a vlastných slov objavil dovtedy neznáme nemecké drevorubačské usadlosti (unbekannte deutsche holzhauersiedlungen fand). ${ }^{54}$

vtedajším riaditel'om Lipského inštitútu germanistiky (Leipziger Germanistischen Instituts). Frings vypracoval plán na vytvorenie Atlasu, ktorý následne zaslal k vedúcim postavám germanistiky na pražskej Nemeckej Karlovej univerzite, Ericovi Gierachovi a Ernstovi Schwarzovi. Pozri: ENGELS, Heinz: Aufbau und Anliegen des Sudetendeutschen Wörterbuchs. In: Bohemia. Zeitschrift für Geschichte und Kultur der böhmischen Länder. tom. 24, vol. 2, 1983, s. 348-357.

51 SCHWARZ, E.: Nachruf, s. 401-403.

52 Prvou osobou pôsobiacou v sudetonemeckom vlastivednom výskume, ktorá spomenula malokarpatských Huncokárov bol historik a sociológ Eugen Lemberg. V roku 1925 sa zúčastnil v rámci vysokoškolského spolku Wolframsbruder zájazdu na Slovensko. Táto cesta mala predovšetkým vedecký charakter. Pozri: LEMBERG, Eugen: Volkskundliche Übersicht. In: Die Deutschen in der Slowakei und Karpathorussland. hg. E. Winter, Münster : Aschendorffsche Verlagsbuchhandlung, 1926, s. 41-43. Po skončení druhej svetovej vojny koordinoval Lemberg s manželmi Beranekovcami založenie výskumného pracoviska - Collegium Carolinum v Mníchove. Ciel'om tohto pracoviska bolo iniciovat' a koordinovat' vedecký záujem a zároveň mapovat' podiel Nemcov na kultúre a histórii českých krajín a v menšej miere aj Slovenska. Pozri: LOZOVIUK, P.: Etnicita a nacionalismus, s. 27. Pred systematickým sudetonemeckým výskumom z prvej polovice 20. storočia boli Huncokári spomenutí v nemecko-jazyčnej vedeckej literatúre prostredníctvom článku Richarda Pfaundlera z roku 1910. Pozri: PFAUNDLER, Richard: Das Verbreitungsgebiet der Deutschen sprache in Westungarn. In: Deutsche Erde. tom. 9, vol. 1, 1910, s. 14-18.

53 BERANEK, Franz Josef: Beiträge zur Kenntnis des Volkstums der deutschen Holzhacker in den Kleinen Karpathen I. In: Karpatenland. tom. 12, vol. 2, 1941, s. 148-155. V októbri toho istého roka Beranek uviedol, že táto svojrázna skupina l’udí (eigenartiges Völkchen) bola sudetonemeckej verejnosti predstavená len nedávno. Pozri: BERANEK, Franz Josef: Die letzten Deutschen von Ungvar. In: Tagesbote. tom. 78, vol. 491, 1928, s. 3. Samuel Sandtner pochádzal z malokarpatskej podhorskej obce Limbach. Mal nemecký pôvod, ku ktorému sa začal hlásit' v priebehu 20. rokov 20. storočia. Rovnako ako Beranek, aj on sa živil učením nemčiny. Pozri: Deutsche Volkshochschule in Pressburg. In: Neues Pressburger Tagblatt. tom. 2, vol. 228, s. 8.

${ }^{54}$ Správu zo svojej cesty následne Bier uverejnil v časopise Karpathenland. V ňom uviedol, že v lesoch medzi obcami Modra, Pernek a Sološnica v tej dobe žilo zhruba 500 Huncokárov. Pozri: BIER, Wilhelm: Von den deutschen Holzfällern in den Kleinen Karpathen. In: Karpathenland. tom. 3, 1930, vol. 1, s. 28-30. 
Na konci dvadsiatych, resp. začiatkom tridsiatych rokov 20. storočia Beranek absolvoval niekol'ko okružných ciest po malokarpatských horách, počas ktorých začal spoznávat' huncokársku komunitu. ${ }^{55}$ Materiály z týchto ciest následne spracoval v niekol'kých článkoch, ktoré mali rovnaký názov - Nemeckí drevorubači v Malých Karpatoch (Deutsche Holzhacker in den Kleinen Karpathen). V prvom článku z roku 1929, ktorý vyšiel v denníku Tagesbote ${ }^{56}$ sa rečnícky pýtal, či v tomto predpolí (Vorlandorte $)^{57}$ našli Nemci svoje posledné útočisko. ${ }^{58}$ Text článku mal predovšetkým etnografický charakter.

Zaujímavá je komparácia Huncokárov a ostatného nemectva žijúceho priamo v malokarpatských obciach (Dorfdeutschen). $\mathrm{V}$ prvom rade ich odlišuje profesijným zameraním. Huncokári boli bud' drevorubačmi (holzhacker), alebo hájnikmi (hegerer). Nemci žijúci v obciach zas boli prevažne vinohradníkmi (Weinbauern). ${ }^{59}$ Obe skupiny nemecky hovoriaceho obyvatel'stva však odlíšil aj fyziognomicky. Huncokári boli podl'a jeho slov stavbou tela (körperbau) ${ }^{60}$ šl'achovití (sehniger) a svetlí (lichter). ${ }^{61}$ Odlišný bol aj ich pôvod. Beranek popísal tiež niektoré huncokárske usadlosti. Explicitne uvádza predovšetkým lokality: Biely Kríž, ${ }^{62}$ Lindava (Lindavský les), usadlost’ pri zrúcanine bývalého kláštora svätej Ka-

${ }^{55}$ BERANEK, F. J.: Beiträge zur Kenntnis, s. 148-155. V tomto období sa Beranek vo zvýšenej miere venoval aj výskumu nemecky hovoriacich Habánov. Pozri: KUBISA, T.: Franz Beranek, s. 76-89.

${ }^{56}$ BERANEK, Franz Josef: Deutsche Holzhacker in den Kleinen Karpathen. In: Tagesbote. tom. 79, vol. 156, 1929, s. 3-4.

${ }^{57}$ Beranek mal na mysli horské územie Malých Karpát.

58 Vhodným materiálom na komparáciu s Beranekovým článkom je cestopisná práca slovenského spisovatel’a Ferdinanda Dúbravského z roku 1910. Spomína v nej okrem iného aj Huncokárov, o ktorých tvrdí, že síce boli Nemcami, ale poslovenčenými. Pozri: DÚBRAVSKÝ, Ferdinand: Malé Karpáty a Bielá Hora. Turistická úprava po juhozápadnej čiasti prebudeného Slovenska. Olomouc: Romuald Promberger, 1910, s. 27.

${ }^{59}$ BERANEK, F. J.: Deutsche Holzhacker, s. 3-4.

${ }^{60}$ Zaujímavost'ou je, že termín stavba tela (körperbau) patril v rámci rasového výskumu Hlavného rasového a osídl'ovacieho úradu SS (Rasse- und Siedlungshauptamt - RuSHA) na prvé miesto z celkovo troch faktorov, ktoré určovali rasu. Pozri: NOVOTNÝ, R.: Národnost, rasa a pospolitost, s. 145 .

${ }^{61}$ BERANEK, F. J.: Deutsche Holzhacker, s. 3-4. Svetlost'ou mal pravdepodobne na mysli farbu vlasov. Pozoruhodné je, že sa Beranek vyhol fyziognomickému porovnaniu Huncokárov a Slovákov. Spôsobené to však môže byt' tým, že v tejto dobe ešte vo svojich textoch nepoužíval nacistickú rasovú terminológiu. Tú po prvý raz implementoval v roku 1939 vo svojej štúdii, ktorá sa týkala pardubického jazykového ostrova. Uviedol, že „nemecká krv“ („deutsches blut") tam žijúcich nemeckých osadníkov obohatila český národ. Pozri: BERANEK, Franz Josef: Geschichte der untergegangenen schlesisch-glätzischen Volksinsel bei Pardubitz in Ostböhmen. In: Schlesisches Jahrbuch. tom. 11, vol. 1, 1939, s. 153-167.

62 V literatúre sa pre túto usadlost' vyskytuje taktiež pomenovanie - Kotzmundov dom (Haus Kotzmund). Pozri: MARKUS, Marian: Die deutschen Holzfäller der Kleinen Karpaten - Ein Vortrag des Heimat und Kulturseminars in Bernried am Starnberger See am 7. April 2009. In: Karpatenblatt. tom. 18, vol. 5, 2009, s. 7. 
Franz Josef Beranek a jeho výskum nemecky hovoriacich drevorubačov ...

taríny (Katarínka), ${ }^{63}$ usadlosti pri Plaveckom hrade a Smoleniciach. Najväčšou udalost’ou, ktorá sa počas roka udiala,bol pre Huncokárov sviatok svätého Vincenta. ${ }^{64}$ Podl'a Beraneka, počas tohto dňa ponechávajú všetku prácu a odchádzajú do obecných kostolov, kde sú pre nich usporadúvané omše. 65 Článok zakončil slovami, v ktorých zdôraznil, že Huncokári zohrávajú dôležitú úlohu v rámci ostatných nemeckých menšín žijúcich na východe Európy.

0 rok neskôr napísal Beranek článok s rovnakým názvom v denníku Nové bratislavské noviny (Neues Pressburger Tagblatt).66 Obsahovo je síce na prvý pohl'ad identický s jeho predchodcom z roku 1929, no vydanie z roku 1930 je doplnené o viaceré nové informácie. V úvodných vetách textu Beranek priam nadnesene uviedol, že špecifickost' horskej krajine Malých Karpát dodávajú údery sekerou pochádzajúce od tamojších drevorubačov. ${ }^{67}$ Povrch krajiny (Das flache Land) popisuje ako slovenský. Úzke horské lesné pásmo od Dunaja, ktoré sa tiahlo pozdĺž železničnej trate Kúty-Trnava až d'alej po severovýchod bolo obývané Nemcami. ${ }^{68}$ Ďalej Beranek uvádza, že v cirkevných matrikách vtedajších slovenských obcí na okraji Malých Karpát bolo možné zhruba od roku 1750 nájst' viacero priezvisk, ktoré sa spájajú s Huncokármi. Za typicky huncokárske považuje predovšetkým nasledovné: Aschenschwandtner, Tanglmaier, Hirner, Graus, Reisenauer, Reisinger, ${ }^{69}$ Kern, Haverl, Langer, Gschill, Gschwandtner, Grosshappel, Hofer ${ }^{70}$ a d'alšie. ${ }^{71}$ Rodiny Hirnerovcov a Hoferovcov majú podl'a neho pôvod v Tirolsku. Reisenauerovci a Langerovci zas pochádzajú z Moravy, resp. Sliezska. Ostatné huncokárske rodiny mali pôvod v Štajersku. ${ }^{72}$ Zaujímavý je Beranekov pohl'ad na

\footnotetext{
${ }^{63}$ Dúbravský v roku 1910 uviedol, že tam stáli dva huncokárske domy. Pozri: DÚBRAVSKÝ, F.: Malé Karpáty, s. 38.

${ }^{64}$ Svätý Vincent zo Zaragozy (? - 304). Pre viac informácií ohl’adne svätého Vincenta pozri: SLOBODOVÁ-NOVÁKOVÁ, K. et al.: Rozšírenie kultu sv. Vincenta, s. 7-28.

${ }^{65}$ BERANEK, F. J.: Deutsche Holzhacker, s. 3-4.

66 BERANEK, Franz Josef: Deutsche Holzhacker in den Kleinen Karpathen. In: Neues Pressburger Tagblatt. tom. 1, vol. 17, 1930, s. 3-4.

${ }^{67}$ BERANEK, F. J.: Deutsche Holzhacker, s. 3-4.

${ }^{68}$ BERANEK, F. J.: Deutsche Holzhacker, s. 3-4.

${ }^{69}$ Usadlost' s názvom Reisinger (Kolárske) sa ako jediná spomedzi huncokárskych usadlostí nachádza na prvom vojenskom mapovaní $(1763$ - 1787). Pozri: KRAJČOVIČ, P.: Problematika huncokárskeho osídlenia, s. 133-142.

${ }^{70}$ Používanie priezviska Hofer bolo rozšírené aj medzi nemecky hovoriacimi Habánmi. Pozri: LIST, Berta: Aufgaben und Arbeitsweisen der sippenkundlichen Forschung mit besonderer Berücksichtigung der Slowakei. In: Deutschtumsfragen im Nordkarpatenraum. tom. 1, vol. 2, 1944, s. 78-89.

${ }^{71}$ BERANEK, F. J.: Deutsche Holzhacker, 1930, s. 3-4.

72 BERANEK, F. J.: Deutsche Holzhacker, s. 3-4. Štajerský pôvod istej časti huncokárskej populácie spomenul v roku 1882 ostrihomský kanonik a historik Pavol Jedlička. Ostatné huncokárske rodiny mali podla jeho slov rakúsky pôvod. Pozri: JEDLICSKA, Pál: Kiskárpáti
} 
skupinovú identitu Huncokárov. Domnieva sa, že vzhl’adom na rozdielny pôvod jednotlivých rodín bola vytvorená zlúčením (Verschmelzungserzeugnis). Huncokársku populáciu podl'a neho tvorilo zhruba 800 obyvatel'ov, ktorí žili na vyše 40 usadlostiach. ${ }^{73}$ Vo všeobecnosti považoval Beranek Huncokárov za ohrozenú komunitu. Napriek tomu si však dokázali uchovat' svoju jedinečnost' a dokonca dokázali ponemčit' niekol'ko Slovákov (Slowaken einzudeutschen). ${ }^{74}$ Mimoriadne vážení boli Huncokári predovšetkým $v$ rámci svojho remesla viažuceho sa na lesné hospodárstvo. S obl'ubou ich pozývali na svoje panstvá šlachtické rody z celej rakúsko-uhorskej monarchie. Drevorubači a hájnici pochádzajúci z malokarpatských rodín sa tak kvôli svojmu remeslu odst'ahovali napríklad do bezprostredného okolia Nitry, Olomouca, Košíc, Sedmohradska či Bukoviny. ${ }^{75}$ Text končí opisom Beranekovho stretnutia so starou ženou (Huncokárkou). Ked' sa dotkli témy jazyka, tak mu povedala, že sa jej vôbec nepáči, ako sa zaobchádza s nemeckým jazykom. ${ }^{76} \mathrm{O}$ výsledkoch svojho huncokárskeho výskumu z obdobia rokov 1928 - 1930 Beranek referoval počas príležitosti zasadnutia Juhovýchodonemeckej výskumnej spoločnosti (Südostdeutschen Forschungsgemeinschaft). Na tejto

emlékek. Vöröskőtől-Szomolányig : Hely és müvelődéstörténeti tanulmány. Budapest : Nyomatott a Hunyadi Mátyás Intézetben, 1882, s. 317-318.

${ }^{73}$ BERANEK, F. J.: Deutsche Holzhacker, s. 3-4. Naproti tomu podl'a Beranekovho odhadu z roku 1928 tvorilo huncokársku populáciu zhruba 700 osôb. Pozri: BERANEK, F. J.: Die letzten Deutschen, s. 3.

${ }^{74}$ Ferdinand Dúbravský uvádza, že medzi Huncokármi žili slovenské rodiny Tulákovcov, Ribnikárovcov a Vrátnych. Pozri: DÚBRAVSKÝ, Ferdinand: Krvavý hostinec a iné povesti. Prešov : Nakladatel'ský podnik - Kultura Prešov, 1922, s. 16.

75 Odchod drevorubačských rodín do iných regiónov v rámci vtedajšej rakúsko-uhorskej monarchie nemusel nutne súvisiet' s kvalitou ich práce. Rakúsky geograf a historik Egon Lendl uviedol, že mnohé rodiny nemecky hovoriacich drevorubačov pochádzajúce z juhozápadného Slovenska a taktiež Spiša boli presídl'ované z dôvodu preludnenia ich doterajších usadlostí. Pozri: LENDL, Egon: Der deutsche Volksboden im Nordkarpatenraum. In: Karpatenland. tom. 12, vol. 1, 1941, s. 12-20. Je zaujímavé, že Beranek nespomenul aj drevorubačské usadlosti nachádzajúce sa v regióne súčasnej Podkarpatskej Rusi. Rovnako ako v Malých Karpatoch, aj tam žili nemecky hovoriaci drevorubači. Predkovia rodín týchto drevorubačov, ktorí žili v obciach Nemecká Mokrá (Deutsch-Mokra), Ust' Čorna (Königsfeld) a Ruská Mokrá (Russisch-Mokra). Výskum tu v tridsiatych rokoch 20. storočia vykonával predovšetkým Beranekov osobný priatel', známy rakúsky etnológ Richard Wolfram. Pozri: WOLFRAM, Richard: Die Frühform des Ländlers. In: Zeitschrift für Volkskunde. tom. 43, vol. 5, 1935, s. 129-151. Beranek osobne navštívil drevorubačskú usadlost' v Nemeckej Mokrej, pravdepodobne v roku 1927. V Inštitúte pre zahraničné vzt'ahy (Institut für Auslandsbeziehungen) sú uchované fotografie, ktoré počas výskumu vyhotovil. Pozri: ZAUNER, Anton et al.: DeutschMokra, Königsfeld: eine deutsche Siedlung in den Waldkarpaten. Volkskundliche Darstellung. Stuttgart : Verlag - Hilfsbund Karpatendeutscher Katholiken, 1979, s. 183, 302, 307, 309.

${ }^{76}$ BERANEK, F. J.: Deutsche Holzhacker, s. 3-4. Porov. PANCZOVÁ, Z.: Pôsobenie Franza J. Beranka na Slovensku, s. 23-39. Týmto chcel Beranek pravdepodobne nepriamo naznačit' sudetonemeckému okruhu vedeckých pracovníkov dôležitost’ budúceho etnografického výskumu Huncokárov. 
Franz Josef Beranek a jeho výskum nemecky hovoriacich drevorubačov ...

udalosti, ktorá sa konala 25. septembra 1932 prednášal predovšetkým o nárečí Huncokárov. ${ }^{77}$

Viac než jednu dekádu nenapísal Beranek o Huncokároch žiadny článok ani odbornú štúdiu. Až v roku 1941 uverejnil monografiu s názvom: Nemecké osídlenie bratislavského kraja (Die deutsche Besiedlung des Pressburger Grossgaus). ${ }^{78}$ Rovnako ako v minulosti, aj v tomto roku (1941) zdôraznil svoje obavy o ich osud. Naznačil, že môžu dopadnút' ako Habáni. Po nich, podl'a jeho slov, ostali len relikty v podobe priezvisk a tri habánske dvory (Sobotište, Moravský Svätý Ján, Vel’ké Leváre) s určitou formou obecnej správy. ${ }^{79}$ Ohrozenie pre Huncokárov prichádzalo predovšetkým zo severnej strany Malých Karpát. Tam podl'a neho dochádzalo najčastejšie k slovakizácii huncokárskeho obyvatel'stva. ${ }^{80}$ Sám priznáva, že je to paradoxné. Ked’že v nižšie položených oblastiach malokarpatského územia dochádza k opaku (gegenteil), čiže ponemčovaniu slovenských rodín. ${ }^{81}$ Kapitolu o Huncokároch uzatvára tým, že osídlenie alpských drevorubačov je nutné chápat’ predovšetkým ako osobitný proces (Einzelvorgang) príchodu ich krvi (ihre Blüte). ${ }^{82}$ Ten nastal

\footnotetext{
77 BERANEK, F. J.: Beiträge zur Kenntnis, s. 148-155. Huncokárske nárečie podl’a Beraneka obsahovalo niektoré čisto (rein) juhobavorské (südbayrische) slová. Avšak prevládal v ňom predovšetkým stredobavorský element (mittelbayrische Element). Pozri: BERANEK, F. J.: Deutsche Holzhacker, s. 3-4. Výskyt juhobavorských slov v huncokárskom nárečí je možné vysvetlit' aj na základe ich zmiešaného pôvodu. Juhobavorské nárečie sa totiž vyskytuje predovšetkým v Tirolsku, odkial' prišla aj istá čast' huncokárskych rodín. Pozri: BERANEK, Franz Josef: Das Habanerdeutsch. In: Deutsche Stimmen. tom. 10, vol. 4, 1943, s. 4.

${ }^{78}$ BERANEK, F. J.: Die deutsche Besiedlung, s. 91. Po roku 1941 pracoval Beranek na svojom výskume Huncokárov aj so svojou manželkou. Spolu spracovávali aj niektoré cirkevné matriky. Určit' exaktné miesta (obce, mestá), odkial' huncokárske obyvatel'stvo prišlo sa im nepodarilo. Podarilo sa im však napríklad zistit', že čast' nemecky hovoriaceho obyvatel'stva z vtedajšieho Solivaru pri Prešove (Deutsch-Salzburg) prišla z obce Halsenbach (západné Nemecko). Pozri: WOLF-BERANEK, Hertha: Volkskundliches aus Deutsch-Salzburg. In: Deutsche Stimmen. tom. 10, vol. 28, 1943, s. 4.
}

${ }^{79}$ BERANEK, F. J.: Die deutsche Besiedlung, s. 85.

${ }^{80}$ Partnerský výber bol u Huncokárov až do medzivojnového obdobia obmedzený prevažne na členov ich vlastnej skupiny. Prísna endogamia a nedostatok kontaktov ich nútili využívat' každú príležitost' na získanie partnera. Manželské preferencie mladých l'udí nekontrolovali len rodičia a príbuzenstvo, ale v zásade celé lokálne spoločenstvo. Pozri: BOCÁNOVÁ, Martina: Huncokári - horskí l'udia a ich vymedzenia voči majorite. Stereotypné obrazy, atraktivita a nebezpečenstvo iných. In: My a Oni - Domácí a cizí v lidové tradici. zost. P. Č́íhal, Uherské Hradiště : Slovácké muzeum v Uherském Hradišti, 2019, s. 119131; SLOBODOVÁ-NOVÁKOVÁ, K.: Partnerský a erotický život, s. 67-80.

${ }^{81}$ BERANEK, F. J.: Die deutsche Besiedlung, s. 85.

${ }^{82}$ Spomenutie krvi (blut) v texte môže byt' spôsobené vtedajším vplyvom nacistickej rasovej doktríny. Vyskytovala sa vo vel'kej časti textov vtedajších pracovníkov pôsobiacich v rámci všetkých vedných odborov. Slovo krv sa používalo hlavne ako súčast' slovného spojenia „nemecká krv“ („,deutsches Blut"). Tento výraz bol vo vtedajšom nacistickom ponímaní chápaný v zmysle genealogickom a dedičnom (genetickom). Pozri: NOVOTNÝ, R.: Národ- 
v rámci druhej etapy, tzv. východnej kolonizačnej epochy (Ostkolonisationsepoche). ${ }^{83}$

V roku 1941 publikoval Beranek v časopise Karpatenland prvú čast' svojej azda najznámejšej štúdie o Huncokároch s názvom Príspevky k poznaniu národnej povahy nemeckých drevorubačov v Malých Karpatoch (Beiträge zur Kenntnis des Volkstums der deutschen Holzhacker in den Kleinen Karpathen). V tejto práci publikoval poznatky týkajúce sa huncokárskych povestí a l'udového rozprávania. Zaznamenané rozprávania neuverejnil v huncokárskom nárečí, ale v spisovnej nemčine (Hochdeutsch). Tematicky sú rozdelené nasledovne:

1. Bosorky a čarodejníci (Hexen und Zauberere) ${ }^{84}$

2. Zmok (Heinspiegel)

3. zakopané poklady (Vergrabene Schätze)

4. potrestané zločiny (Verstrafter Frevel)

5. duchovia a strašidlá (Geister und Totenspuk) ${ }^{85}$

Motívy rozprávaní a povestí z tejto štúdie patria k všeobecne zdiel'aným v stredoeurópskej tradícii. Väčšinou sú lokálnymi variantami poverových rozprávaní, ktoré sú známe aj v prostredí slovenského etnika. Ich špecifickost' však spočíva práve v tom, ako do seba zakomponovali huncokárske reálie. ${ }^{86}$ Okrem toho je možné vysledovat' aj určité náznaky reflexie vzájomných vzt’ahov medzi Huncokármi a majoritným slovenským obyvatel'stvom. ${ }^{87}$

nost, rasa a pospolitost, s. 93. Beranek toto slovné spojenie v texte nepoužil. Avšak aplikovala ho jeho kolegyňa Berta List. Tá vo svojom článku, v ktorom analyzovala Beranekove zistenia o Habánoch usúdila, že „nemecká krv“ (,deutsches Blut") Habánov je na západnom Slovensku stále prítomná. Dôkazom toho sú ich ešte stále sa vyskytujúce priezviská. Pozri: LIST, B.: Aufgaben und Arbeitsweisen, s. 78-89.

${ }^{83}$ BERANEK, F. J.: Die deutsche Besiedlung, s. 85.

${ }^{84}$ Čarodejníctvo a bosoráctvo bolo mimoriadne vyhl'adávanou tematikou nacistických etnografických výskumov. Rakúsky germanista a folklorista Otto Höfler napríklad zobrazil čarodejnice ako germánskych bojovníkov bojujúcich proti démonickým silám nadprirodzenými prostriedkami. Tieto myšlienky zaujali taktiež popredných nacistických pohlavárov Heinricha Himmlera a Alfréda Rosenberga. Pozri: RABINBACH, Anson et al.: The Third Reich Sourcebook. Berkeley - Los Angeles : University of California Press, 2013, s. 108.

85 BERANEK, F. J.: Beiträge zur Kenntnis, s. 148-155.

86 PANCZOVÁ, Zuzana: Zaniknutý svet malokarpatských „Huncokarov“ v odraze poverových rozprávaní. In: Zaostrené na kultúrne dedičstvo. Prierez starostlivostou o kultúrne dedičstvo malokarpatského regiónu. Zborník príspevkov odborného seminára. zost. M. Škrovina, Svätý Jur : Academia Istropolitana Nova, 2011, s. 14-21. Čast' huncokárskych povestí a l’udových rozprávaní sa nachádza aj v archívnom fonde Ústavu etnológie SAV, konkrétne v jeho časti nazvanej Slovenské l'udové rozprávania (Slowakische Volkserzählungen). Pozri: PANCZOVÁ, Z.: Pôsobenie Franza J. Beranka na Slovensku, s. 23-39.

${ }^{87}$ Majoritné obyvatel'stvo, hlavne tá čast’ z neho, ktorá s Huncokármi neprichádzala do priameho kontaktu, bola presvedčená o ich divokosti a nevychovanosti. Hory, ktoré boli pre nich symbolom nebezpečenstva preniesli túto charakteristiku aj na l'udí, preto sa na nich viazali obavy z neznámeho. Pozri: BOCÁNOVÁ, M. Huncokári - horskí l’udia, s. 119-131. 
Franz Josef Beranek a jeho výskum nemecky hovoriacich drevorubačov ...

Istú čast’ z povestí však nezaznamenal Beranek, ale rakúsky etnológ a historik Walter Kuhn. ${ }^{88}$ Ten v roku 1932 uskutočnil krátku študijnú cestu, počas ktorej navštívil Bratislavu, Svätý Jur, Pezinok a Limbach. Okrem toho však navštívil aj huncokárske usadlosti. Počas návštevy zaznamenal niekol'ko poverových rozprávaní a povestí. Všetky jeho poznámky, medzi ktorými sa nachádzali aj zapísané povesti, sa však podl'a jeho vlastných slov stratili v roku 1945.89

Druhá čast' Beranekovej štúdie vyšla v roku 1942. ${ }^{90}$ Tematicky ju rozdelil na prácu (Arbeit), zvyky (Sitte) a obyčaje (Brauchtum). Podla Beraneka Huncokári nedostávali za svoju prácu dennú mzdu, ale pracovali na dohodu. Ich pracovný čas v lete začínal od 6. hodiny ráno do 9. hodiny večer. S jednou dvoj až trojhodinovou prestávkou. V zime pracovali od 8. hodiny ráno do 16 . hodiny poobede s jednou hodinovou prestávkou na obed. Zo sociálnych príčin museli pracovat' už jedenást'roční chlapci. ${ }^{91}$ Niektorí drevorubači museli dokonca pracovat' až do 80 tky. ${ }^{92} \mathrm{Na}$ práci v lese sa zúčastňovali aj ženy. ${ }^{93}$ Okrem peňažnej odmeny očakávali Huncokári aj naturálie. Tie väčšinou pozostávali z krmiva pre hospodárske zvieratá či palivového dreva. Výšku naturálií určovali zamestnávatelia.

Beranek opísal aj huncokárske príbytky a ich historický vývoj. Podl'a tradičného rozprávania žili drevorubači, ktorí prišli v 18. storočí v primitívnych chatkách, ktoré boli postavené bezprostredne na zemi. Mali rovnú strechu a boli chatrne pozbíjané. Neskôr si postavili zruby pokryté dlhými šindl'ami, ktoré mali len dve izby. Jedna bola pre l'udí

\footnotetext{
${ }^{88}$ Kuhn bol špecialistom na problematiku etnických enkláv medzivojnového obdobia. Sám pochádzal z nemeckého jazykového ostrova, ktorý sa nachádzal vo východnej oblasti rakúskeho Sliezska s centrom v mestečku Bielsko (vtedy Bielitz). Vo svojich prácach sa snažil definitívne teoreticky a metodologicky zakotvit' tzv. vedu o jazykových ostrovoch (Spachinselforschung). $\mathrm{V}$ jej rámci sa v nemecky hovoriacich krajinách od 20. rokov 20. storočia postupne profilovalo etnografické štúdium etnických enkláv (Sprachinselvolkskunde) ako špeciálna etnografická subdisciplína. Pozri: LOZOVIUK, P.: Etnicita a nacionalismus, s. 15-16.

${ }^{89}$ CAMANN, Alfred et al.: Volkserzählung der Karpatendeutschen - Slowakei. Teil I. Marburg : N.G. Elwert Verlag, 1981, s. 45-47.

90 BERANEK, Franz Josef: Beiträge zur Kenntnis des Volkstums der deutschen Holzhacker in den Kleinen Karpathen II. In: Karpatenland. tom. 12, vol. 3-4, 1942, s. 306-313.

91 Pavol Jedlička uviedol, že huncokárske deti pracovali v lesných škôlkach. Pozri: JEDLICKA, P.: Kiskárpáti emlékek, s. 318.

${ }^{92}$ Huncokári sa predovšetkým počas 20. rokov 20. storočia ocitli v t’ažkej sociálnej situácii. Bolo to spôsobené aj pozemkovou reformou, ktorá nastala v období prvej Československej republiky. Táto reforma zasiahla vel'kou mierou Pálfiovský rod, ktorý vo svojich službách zamestnával značnú čast' huncokárskej populácie žijúcej v Malých Karpatoch. Pozri: KOVAČIK, Michal: K problematike posledných Pálffyovcov na hrade Červený Kameň a ich vzt'ah k obyvatel'om okolitých obcí. In: Studia Historica Nitriensia . tom. 17, vol. 1, 2013, s. 40-53.

${ }^{93}$ Huncokárske ženy boli cenené pre ich dobrý zdravotný stav, silu, výdrž a pracovné návyky. Pozri: SLOBODOVÁ-NOVÁKOVÁ, K.: Partnerský a erotický život, s. 67-80.
} 
a jedna pre domáce zvieratá. ${ }^{94} \mathrm{~V}$ časoch Beranekovho výskumu žili v pozdĺžnych domoch, ktoré boli natreté sýtomodrou farbou. $\mathrm{V}$ týchto domoch žili zvyčajne dve až tri rodiny. ${ }^{95}$ Materiál na stavbu pozostával z pálenej tehly a kameňa. Kvalitnejšie obydlia mali podl'a jeho slov rodiny žijúce na lokalitách Polámané a Sasková. Tie mali viac izieb.

Vo vol'nom čase Huncokári radi hrávali kolky. ${ }^{96}$ Tie sa nachádzali pri viacerých huncokárskych usadlostiach. Oblúbeným artiklom bol u nich tabak, ktorý bud' fajčili z drevených fajok, alebo dokonca šnupali. Fajčili dokonca aj niektoré ženy. Aj tentokrát sa Beranek dotkol problematiky zmiešaných manželstiev. Pre mladého drevorubača bolo takmer samozrejmé, že si vezme za ženu dcéru iného drevorubača. K zmiešaným manželstvám ${ }^{97}$ dochádzalo zvyčajne na severnej strane Malých Karpát.

Beranek opísal aj huncokárske svadobné zvyky, ktoré sa odlišovali od slovenských. Sviatok ich patróna, svätého Vincenta, bol podl'a neho znakom asimilačnej schopnosti Huncokárov. Dôkazom bolo to, že s nimi tento sviatok oslavovali mnohí Slováci. V najväčšom drevorubačskom osídlení na Piesku stála od roku 1862 kaplnka, ktorá bola zasvätená svätej Márii Magdaléne. 22. júla sa v kaplnke uskutočňovala omša. Deň na to sa v Panskom dome (Herrenhaus) na Piesku konala zábava. ${ }^{98}$ Typická bola pre ňu cigánska muzika a tanec. Omše aj zábavy sa zúčastňovali huncokárske rodiny zo všetkých okolitých revírov. ${ }^{99}$

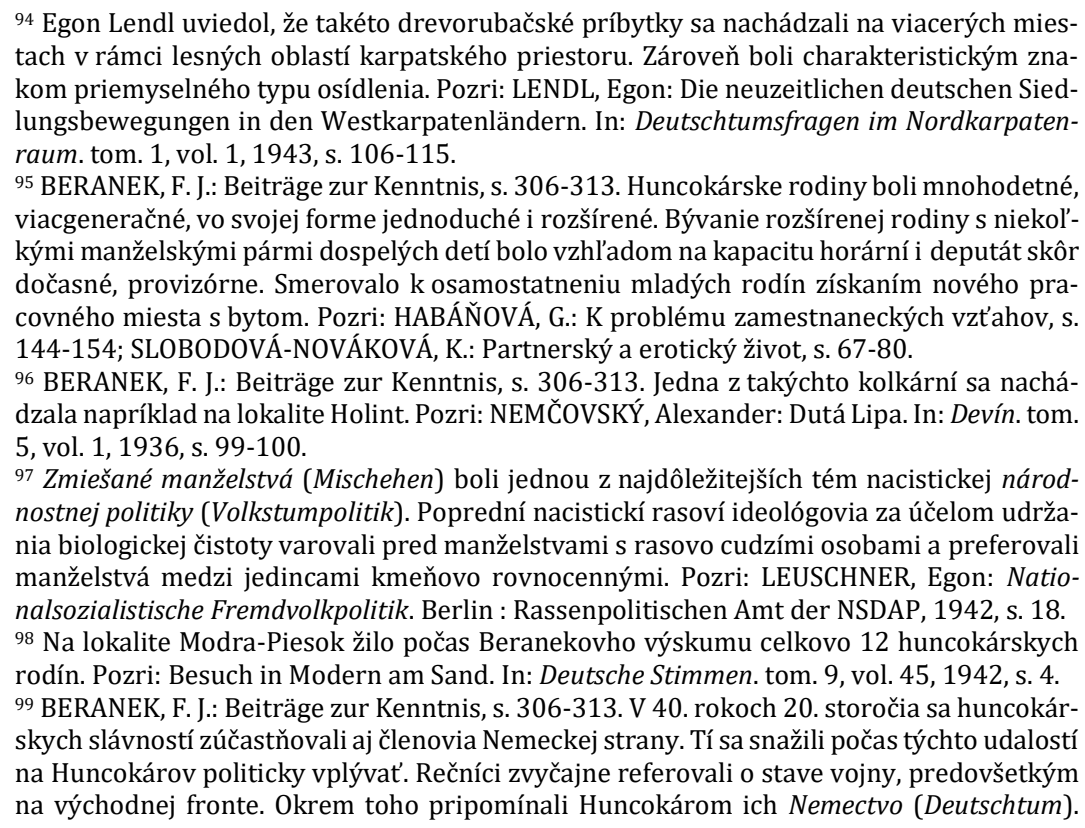


Franz Josef Beranek a jeho výskum nemecky hovoriacich drevorubačov ...

Najzaujímavejšou pasážou v rámci tejto Beranekovej štúdie je jeho zmienka o l'udovom liečitel'stve. Starú l’udovú medicínu mali Huncokári v krvi, pretože žili d'aleko od najbližších obcí, kde sa nachádzala lekárska pomoc. Na bolesti hlavy používali obklad z nastrúhaných zemiakov. Bradavice potierali rastlinami ako napríklad lastovičník (Warzenkraut) či l'ul'kovec (Tollkirsche). Lastovičník rástol len na niektorých miestach, napríklad nad lokalitou Harmónia v blízkosti Modry. Na liečebné účely im však slúžili aj rôzne živočíšne mastičky - proti pl'úcnej chorobe jazvečia mast', mast' zo psa sa používala okrem pl'úcnych aj na srdcové choroby. Vel'mi vážené však bolo pôsobenie hadej masti, ktorá sa pripravovala tak, že do tiel mŕtvych hadov urobili zárezy a následne ich vystavili pôsobeniu slnečného žiarenia. To spôsobovalo, že hadí tuk odkvapkal, z čoho následne vyrábali mast'. Kedysi dokonca z hadích kostí vyhotovovali aj retiazky na hodinky. 100

Text je zakončený Beranekovým obdivom k huncokárskej komunite. Ich svetom bol podl'a jeho slov les ${ }^{101}$ so svojou hojnost'ou rastlín a zveri. Ich spôsob života im zanecháva v génoch špecifickú značku. Berenek plánoval vydat' aj tretiu čast' Príspevkov k poznaniu národnej povahy nemeckých drevorubačov v Malých Karpatoch. V tejto štúdií, ktorá mala vyjst' na prelome rokov 1943/1944 sa chcel dôkladnejšie zaoberat' huncokárskym nárečím. Avšak vzhl'adom na to, že v decembri roku 1943 odišiel zo Slovenska, táto práca nevyšla. ${ }^{102}$

Beranekova práca s názvom Nemecké osídlenie západného Slovenska (Die Deutsche Besiedlung der Westslowakei) ${ }^{103}$ vznikla počas jeho pôsobenia v Kežmarku. ${ }^{104}$ Vo všeobecnosti má predovšetkým opisný charakter. Zameraná je na chronologicky najstaršie germánske a taktiež

Z toho vyplýva, že sa viac menej snažili verbovat' dobrovol'níkov pre vojnové účely. Pozri: Waldkirchweih der Holzhacker. In: Deutsche Stimmen. tom. 8, vol. 29, 1941, s. 6; Modern am Sand. In: Deutsche Stimmen. tom. 8, vol. 31, 1941, s. 4. Niektorí Huncokári pôsobili v ozbrojených zboroch Nemeckej strany (Freiwilige Schutzstaffel - FS). Čast' z nich však slúžila aj v zbraniach SS (Waffen-SS) či jednotkách domobrany (Heimatschutz - HS). Pozri: PETRANSKÝ, I. A.: Perzekúcie nemeckých drevorubačov, s. 488-507.

100 BERANEK, F. J.: Beiträge zur Kenntnis, s. 306-313.

101 BERANEK, F. J.: Beiträge zur Kenntnis, s. 306-313. Tematika lesa bola značne rozšírená aj v nacistickej ideológii. Niektorí autori dokonca spájali germánsku rasovú odlišnost's lesným prostredím. Pozri: SCHAMA, Simon: Landscape and Memory. New York : Vintage books, 1995, s. 118-119.

102 BERANEK, Franz Josef: Stand und Aufgaben der deutschen Mundartforschung in der Slowakei. In: Karpatenland. tom. 13, vol. 2, 1943, s. 60-63.

${ }^{103}$ BERANEK, Franz Josef: Die deutsche Besiedlung der Westslowakei. In: Deutschtumsfragen im Nordkarpatenraum. tom. 1, vol. 1, 1943, s. 56-77.

1040 téme nemeckého osídlenia na západnom Slovensku prednášal Beranek 25. septembra 1942 na kultúrnej udalosti usporiadanej Inštitútom pre výskum vlasti v Kežmarku. Pozri: Nachrichten aus... Käsmark. Karpatendeutsche Hochschulwoche in Käsmark. In: KarpatenPost. tom. 63, vol. 34, 1942, s. 2. 
nemecké osídlenia na Slovensku. 0 nemecky hovoriacich drevorubačoch sa zmieňuje až takmer na konci štúdie. Okrem informácií, ktoré uviedol už v predchádzajúcich prácach dopíňa aj niektoré dovtedy neznáme skutočnosti. Jednou z nich je napríklad zmienka o Huncokároch žijúcich v pohorí Považského Inovca. ${ }^{105}$ Tí sem postupne odchádzali zhruba od roku 1850. Aj vzhl'adom na objavenie nových usadlostí v považsko-inoveckom pohorí uviedol Beranek nový populačný údaj týkajúci sa huncokárskeho obyvatel'stva. Celkovo žilo na slovenskom území vyše 1000 Huncokárov vo viac než 50 sídlach. ${ }^{106}$ Tie boli rozmiestnené od Bratislavy až po okres Bánovce nad Bebravou. ${ }^{107}$ Slovakizáciou boli ohrození predovšetkým Huncokári žijúci v okolí Myjavy a Považského Inovca. Zastavit' tento trend mali podl'a jeho slov predovšetkým novozaložené nemecké školy. ${ }^{108}$

Beranekov výskum Huncokárov sa definitívne skončil v roku 1943. V decembri toho roku ho nemecké autority spolu s manželkou premiestnili do Prahy. ${ }^{109}$ Po skončení druhej svetovej vojny opustil české územie a usadil sa v Nemecku, kde sa opät' začal venovat' výskumnej činnosti. 0 Huncokároch sa posledný raz zmienil v roku 1955 v článku s názvom Bašta Bavorstva (Vorposten des Baierntums). ${ }^{110}$ V ňom uviedol, že horskí

105 Považsko-inoveckým Huncokárom sa venovala aj Beranekova manželka Hertha. Pozri: WOLF-BERANEK, Hertha: Aus dem Sagenschatz der Inowetzdeutschen. In: Deutsche Stimmen. tom. 10, vol. 7, 1943, s. 3-4. Egon Lendl nazval považsko-inovecké osídlenie tzv. dcérskym osídlením (Tochtersiedlung). Pozri: LENDL, E.: Die neuzeitlichen deutschen, s. 106-115.

${ }^{106}$ V roku 1944 vytvoril rakúsky kartograf Walter Neunteufl na základe Beranekových zistení mapu v mierke 1 : 200 000, na ktorej sú zaznamenané okrem iného aj huncokárske usadlosti. Ich celkový počet je 61 a nachádzajú sa na celom území pohoria Malých a Bielych Karpát. Pozri: NEUNTEUFL, Walter: Das Deutschtum im Pressburger Raum (mit drei Karten, drei Schaubildern und einem Ortsverzeichnis). Graz : Südostdeutsches Institut Graz, 1944, 24 s. 107 Nemecky hovoriaci drevorubači žili napríklad v osade Kulháň, ktorá sa nachádzala v okrese Bánovce nad Bebravou. Pozri: LEMEŠ, Vladimír: Osada a polesie Kulháň. In: Zlatníky: prírodopis, história, súčasnost'. Zost. H. Grežd’ová. Zlatníky : Obecný úrad Zlatníky, 2006, s. 115-131.

108 Takéto školy sa nachádzali napríklad v Smoleniciach, Stupave, Malackách, Perneku, Sološnici či na Piesku. Pozri: Schulgründung in Pernek. In: Deutsche Stimmen. tom. 7, vol. 36, 1940, s. 10; Schuleröffnung in Pila. In: Deutsche Stimmen. tom. 8, vol. 10, 1941, s. 6.

${ }^{109}$ Beranekovci museli Slovensko opustit' z donútenia. Celé ich pôsobenie na Inštitúte pre výskum vlasti sa nieslo v znamení antipatie medzi nimi a slovenskými Nemcami. Došlo aj k fyzickej potýčke medzi Beranekovou manželkou a zamestnankyňou Inštitútu Margarétou Urban. Okrem toho sa manželia dostali do iných problémov. Mali totiž odcudzit' jeden z vypožičaných výskumných materiálov. Pozri: FAHLBUSCH, M.: Handbuch der völkischen Wissenschaften, s. 1425. Ich odchod z Inštitútu bol pár vetami zmienený aj vo vtedajšej tlači. Pozri: Aus dem Institut für Heimatforschung. In: Deutsche Stimmen. tom. 10, vol. 51, 1943, s. 9. Zaujímavý je postoj Beraneka k jeho pôsobeniu v Kežmarku. Podl'a jeho vlastných slov potrebovala bratislavská pobočka Nemeckej strany „hlupáka“, ktorý by viedol boj s Johanom Liptákom. Pozri: MORRISEY, Ch.: Ethnic Politics, s. 100-109.

110 BERANEK, Franz Josef: Vorposten des Baierntums. In: Der Zwiebelturm. tom. 5, vol. 1, 1950, s. 77-83. 
Franz Josef Beranek a jeho výskum nemecky hovoriacich drevorubačov ...

l'udia (Bergleute) bavorského pôvodu obývali rozptýlené sídla v karpatských horách už od stredoveku. Ich početnost' bola rozšírená v 18. storočí kolonistami, ktorí prišli z Bavorska a Sliezska. ${ }^{111}$

\section{Záver}

Analýza Beranekovho výskumu nemecky hovoriacich drevorubačov Huncokárov priniesla niekol'ko zistení. Celkový záujem o túto špecifickú komunitu začal v 20. rokoch 20. storočia, počas ktorých sa postupne rozvíjal sudetonemecký etnografický výskum. Beranek, ktorý bol aktívnym členom niekol'kých sudetonemeckých národno-vzdelávacích inštitúcií sa začal zaoberat' tematikou Huncokárov od roku 1928. V období rokov 1928 - 1930 uverejnil niekol'ko článkov, ktoré sa dajú označit' ako vstup do huncokárskej problematiky. Opisoval ich fyziognómiu, usadlosti či dialekt. Vo svojich textoch taktiež vyslovil obavu o existenciu Huncokárov.

Počas druhého obdobia, počas ktorého spolupracoval s niekol'kými nacistickými organizáciami sa začal Huncokárom venovat' v kvalitatívnejšej rovine. $V$ spolupráci s inými bádatel'mi zozbieral huncokárske l'udové rozprávania a povesti, v ktorých okrem iného dokázal vysledovat' aj určité náznaky reflexie vzájomných vzt’ahov medzi Huncokármi a majoritným slovenským obyvatel'stvom.

V druhej časti svojej štúdie z roku 1942 sa podrobnejšie venoval ich práci, zvykom a obyčajom. Načrtol sociálnu situáciu drevorubačskej komunity, charakter osídlenia a ich najznámejšie sviatky. Zaujímavá a doteraz v odbornej spisbe nereflektovaná je aj zmienka o l'udovom liečitel'stve. Tá je odrazom väzby človeka na prírodnú krajinu - les. Posledný jeho príspevok, ešte počas pôsobenia na Slovensku, z časti dopíňa mozaiku vtedajších vedomostí o Huncokároch. Spomenul totiž nedávno objavené usadlosti v pohorí Považského Inovca a zároveň upravil svoje dovtedajšie poznatky o počte ich populácie. Článok napísaný v roku 1955 bol už len akýmsi retrospektívnym zhrnutím jeho niekdajších zistení. Hlavným prínosom Beranekovho výskumu je predovšetkým jeho celistvost'. Zároveň bol posledným bádatel'om, ktorému sa podarilo opísat' túto komunitu predtým než bola v dôsledku povojnových represálií vel'ká čast' jej členov vysídlená.

${ }^{111}$ BERANEK, F. J.: Vorposten des Baierntums, s. 77-83. 